Biol. Neonat. 1959;1:I-IV

\title{
Contents, Vol. 1, 1959
}

\section{NDEX}

Bernheim, M.; Germain, D.; Courtieu, A.-L. et Nivelon, J.-L.: Les rnéningites purulentes néo-natales à Moraxella glucidolytica (Bacterium anitratum). - Neo-natal Suppuratíve Meningitis Due to Moraxella glucidolytica (B. anitratum). - Die durch Moraxella glucidolytica verursachten eitrigen Meningitiden des Neugeborenen 143

Caligara, F.: vide Rooth, G.

Courtieu, A.-L.: vide Bernheim, M.

Fraser, F. C.: vide Heiberg, K.

Fraser, F. C.: vide Pinsky, L.

Germain, D.: vide Bernheim, M.

Geubelle, F.; Karlberg, P.; Koch, G.; Lind, J.; Wallgren, G. et Wegelius, C.: L'aération du poumon chez le nouveau-né. - The Aeration of the Lung in the Newborn Infant.Die Belüftung der Lunge beim Neugeborenen 169

Heiberg, K.; Kalter, H. and Fraser, F. C.: Production of Cleft Palates in the Offspring of Mice Treated with ACTH During Pregnancy. - Production de fente palatine dans la portée de souris traítées par VACTH pendant la gestation. - Entstehung von Gaumenspalten in der Nachkommenschaft von Mäusen, die in der Schwangerschaft mit ACTH behandelt worden sind 33

Jäykkä, S.: The Functional Structure of the Eustachian Valve. - Structure fonctionnelle de la valvule á"Eustachi. - Die funktionelle Struktur der Eustachischen Klappe .... 155

Kalter, H.: vide Heiberg, K.

Karlberg, P.: vide Geubelle, F.

Koch, G.: vide Geubelle, F.

Larroche, J.C; Nodot, A. et Minkowski, A.: Développement des artères et artérioles pulmonaires de la période fætale à la période néonatale. - Development of Pulmonary Arteries and Artérioles from the Fetal to the Neonatal Stage. - Die Entwicklung der Lungen-arterien und

Lungenarteriolen im Ubergang von der Foetal- zur Neugeborenenperiode . 37

Lind, J.: vide Geubelle, F.

Minkowski, A.: Foreword - Avant-propos - Vorwort

Minkowski, A.: vide Larroche, J. C.

Morger, R.: vide Töndury, G.

Nivelon, J.-L.: vide Bernheim, M.

Nodot, A.: vide Larroche, J.C.

Pinsky, L. and Fraser, F. C.: Production of Skeletal Malformations in the Offspring of Pregnant Mice Treated with 6-aminonicotinamide. - Malformations squelettíques provoquées dans la portée de souris traítées, pendant leur gestation, à la 6-aminonicotinamide. - Skelettmißbildungen in der Nachkommenschaft von Mäusen, die während der Gestationsperiode mit 6-Aminonikotinamid behandelt worden waren 106 
Rabiner, S.F.: The Diagnosis of Abnormalities of Blood Coagulation During the Newborn Period. - Diagnostic des troubles de la coagulation à la péríode néo-natale. - Diagnose der Blutgerinnungsstörung während der Neugeborenenperiode 130

Räihä, C.-E.: Prematurity, its Social Consequences, and our Possibilities of Decreasing the Number of Premature Babies. - La prématuríté; ses consequences socíales et les pos-síbilítés de dímínuer le nombre des naíssances prématurées. - Die Prämaturität, ihre so-zialen Folgen und unsere Möglichkeiten zur Herabsetzung der Zahl der Frühgeburten . 113

Rooth, G.; Sjöstedt, S. and Caligaha, F.: The "in vivo" Foetal Oxygen Dissociation Curve. - La courbe de dissociation deVoxygène fætal «in vivo». - Die Dissoziationskurve für foetalen Sauerstoff «in vivo» 61

Schenk, R.: vide Töndury, G.

Sjöstedt, S.: vide Rooth, G.

Töndury, G.; Schenk, R. und Morger, R.: Menschliche Keimlinge mit Nackenblasen.

- $\quad$ Human Embryos with Nuchal Blebs. - Embryons liumains avec bulles de la nuque 68 Tuchmann-Duplessis, H.: Etude des glandes endocrines des anencéphales. Deduction sur les correlations hypophyso-nerveuses du foetus humain (Avec 1 planche en couleurs.)

- $\quad$ A Study of Endocrine Glands in Anencephalus. Deduction on Nervous and Hypophyseal Correlations of the Human Fetus. (With 1 Colour Plate.) - Untersuchungen der endokrinen Drüsen von Anencephalen. Befunde über zentralnervös-hypophysäre Beziehungen beim menschlichen Foetus. (Mit 1 Farbtafel)

Wallgren, G.: vide Geubelle, F.

Wegelius, C.: vide Geubelle, F.

Buchbesprechungen - Book Reviews - Livres nouveaux

153 